\title{
BIOLOGICAL ACTIVITY IN A DEGRADED ALFISOL AMENDED WITH SEWAGE SLUDGE AND CROPPED WITH YELLOW SERRADELA(Ornithopus
} compressus L.)

\author{
José Celis H. ${ }^{*}$, Angela Machuca H.ㄹ, Marco Sandoval E. ${ }^{3}$, and Patricia Morales C. ${ }^{3}$
}

\begin{abstract}
There are few studies about the impact of sewage sludge on the biological properties in Alfisols of the Chilean Coastal Range drylands. Hence, the objective of this study was to evaluate its effect on the microbial respiration and enzymatic activities of a degraded Alfisol located in the Bío Bío Region (Chile) that was cropped with yellow serradela (Ornithopus compressus L.). Sludge was added to the soil at rates of 15, 30, and $60 \mathrm{t}^{-1}$; he following treatments were defined: $\mathrm{L} 15-\mathrm{P}=15 \mathrm{t} \mathrm{ha}^{-1}$ sludge $+O$. compressus; L30-P = $30 \mathrm{t} \mathrm{ha}^{-1}$ sludge + O. compressus; $\mathrm{L} 60-\mathrm{P}=60 \mathrm{t} \mathrm{ha}^{-1}$ sludge $+O$. compressus $; \mathrm{L} 15=15 \mathrm{t} \mathrm{ha}^{-1}$ sludge; $\mathrm{L} 30=30 \mathrm{tha}^{-1}$ sludge; L60 = $60 \mathrm{t} \mathrm{ha} \mathrm{s}^{-1}$ sludge; $\mathrm{CP}$ = non-amended soil, cropped; and $\mathrm{C}=$ non-amended soil, no crop. Soil microorganism activity was evaluated by respirometry. Hydrolytic enzyme activity representative of soil $\mathrm{C}, \mathrm{N}$, and $\mathrm{P}$ cycles was determined. Crop phytomass development was also evaluated. The amount of $\mathrm{C}-\mathrm{CO}_{2}$ produced by soil microorganisms was directly proportional to the dose of amended sludge $(\mathrm{p} \leq 0.05)$. Similarly, greater $\beta$-glucosidase, urease, and acid phosphatase were more active at $60 \mathrm{t}$ sludge $\mathrm{ha}^{-1}$. However, both respiratory and enzymatic activities were greater $(\mathrm{p} \leq 0.05)$ in treatments with sludge-amended soil cropped with $O$. compressus. This greater activity was notorious when the legumes achieved greater phytomass development, thus highlighting the root's stimulating effect on soil biological activity.
\end{abstract}

Key words: Biosolids, respiration, enzymatic activity, degraded soils, remediation.

\section{INTRODUCTION}

Sewage treatment generates enormous quantities of biosolids because of the mechanical, biological, and/or chemical processes applied. Chile generates approximately $600 \mathrm{t} \mathrm{d}^{-1}$ of biosolids, and sewage treatment includes around $90 \%$ of the cities with close to $400 \mathrm{t} \mathrm{d}^{-1}$ produced in Santiago (Marambio and Ortega, 2003). It is evident that a serious environmental problem will occur if final disposal alternatives are not found.

Sewage sludge disposal in the soil improves its physical, chemical, and biological properties (Bonmati et al., 1985; Marambio and Ortega, 2003). Applying sludge to a degraded agricultural soil restores productivity by increasing $\mathrm{pH}$, organic matter $(\mathrm{OM})$ content, $\mathrm{N}, \mathrm{P}$, and $\mathrm{K}$

${ }^{1}$ Universidad de Concepción, Facultad de Ciencias Veterinarias, Casilla 537, Chillán, Chile.

*Corresponding author (jcelis@udec.cl).

${ }^{2}$ Universidad de Concepción, Departamento Forestal, Casilla 341, Los Ángeles, Chile.

${ }^{3}$ Universidad de Concepción, Facultad de Agronomía, Casilla 537, Chillán, Chile.

Received: 12 August 2010.

Accepted: 7 November 2010. levels (García-Gil, 2000; Celis et al., 2008). The increase in $\mathrm{OM}$ levels tends to favor physical parameters, such as aggregation and porosity while also improving root surroundings and plant growth (Darwish et al., 1995). In addition, incorporating sewage increases the biological and enzymatic activity of soils (Pascual et al., 2007; Celis et al., 2009; Arriagada et al., 2009). Soil microorganisms are important in a degraded soil recovery process because they stimulate plant growth through substances, such as hormones and vitamins, which improve structure, reduce erosion, and improve nutrient availability (Waldrop et al., 2003). According to the reported information, using sewage sludge as fertilizers and/or organic regenerators is an interesting option that adds valuable organic components and nutrients (Hernández et al., 1991).

The Chilean Coastal Range drylands have many Alfisol soils with around 2 million hectares of degraded land; it is also one of the natural regions most affected by erosion in Chile (Santibáñez and García, cited by Celis et al., 2007). Intensive agriculture has accelerated this destructive soil process because of unsustainable practices that have eliminated a large part of their organic materials (Celis et al., 2007). Some research has sought to adapt grazing species in these granite soils in order to develop livestock systems 
on drylands where the annual leguminous Ornithopus compressus L. stands out for its good agronomic results (Ovalle et al., 2005; 2006). Soil vegetation cover increases soil $\mathrm{C}$ inputs, thus reducing erosion (Bronick and Lal, 2005). On the other hand, there is information indicating that leguminous roots would favor biological activity in soil (Tang and $\mathrm{Yu}, 1999)$. Thus, the positive effects of this grazing species could reinforce the incorporation of OMrich residues, such as sewage sludge.

Chemical and physical properties have been traditionally used to evaluate soil productivity. However, certain biological parameters are efficient indicators of the recovered state of degraded soils (Crecchio et al., 2004), especially microbial biomass, as well as $\mathrm{C}$ mineralization determined as $\mathrm{CO}_{2}$ (soil respiration), and diverse enzymes produced by organisms present in the soil. Microbial biomass consists of fungi, bacteria, actinomycetes, yeasts, and micro-fauna (such as protozoario); the principal enzyme source is responsible for the soil's biological activity (Joergensen and Emmerling, 2006). Enzyme activity is correlated with the soil's OM because it is important as a precursor of enzyme synthesis (Tabatabai, 1994). The activity of $\beta$-glucosidase is closely related to the $\mathrm{C}$ cycle and is important in $\mathrm{OM}$ decomposition (Bandick and Dick, 1999). Urease hydrolyzes urea and produces $\mathrm{CO}_{2}$ and $\mathrm{NH}_{3}$, and is very important due to its relationship with the $\mathrm{N}$ cycle (Tabatabai, 1994). Phosphatase acid participates in the mineralization of organic $\mathrm{P}$ into soluble inorganic $\mathrm{P}$, which is then available for the plants (Richardson, 2001).

The use of amendments is a factor affecting enzymatic activities in the soil (Joergensen and Emmerling, 2006). The inclusion of organic materials, such as sewage sludges, increases soil microbial biomass by incorporating additional microorganisms into the system and stimulating growth of autochthonous microbiota through the incorporation of new carbon sources (GarcíaGil, 2000; Ros et al., 2003; 2006).

There are no studies about the biological properties of degraded Alfisol soil in Chile's drylands. We hypothesized that a positive effect on soil biological properties is produced when these are amended by sewage and cropped with leguminous species. Hence, the objective of this study was to determine the effect on microbial respiration and enzymatic activity that participate in the $\mathrm{C}, \mathrm{N}$, and $\mathrm{P}$ cycles as a result of applying several doses of sewage sludge to an Alfisol from the Bío Bío Region drylands (Chile) cropped with Ornithopus compressus L.

\section{MATERIALS AND METHODS}

Collection of soil and sludge samples

Alfisol soil samples were obtained at $20 \mathrm{~cm}$ depth from a sector corresponding to the drylands in the Bío Bío Region, Chile $\left(36^{\circ} 37^{\prime} \mathrm{S} ; 72^{\circ} 19^{\prime} \mathrm{W}\right)$. It is taxonomically classified as an Ultic Palexeralfs, which is typically degraded granite-like soil with a clayey texture belonging to the Cauquenes series, with a strong slope (>15\%) and bulk density of $1.6 \mathrm{~g} \mathrm{~cm}^{-3}$ (Celis et al., 2008).

A sewage sample was obtained from the water treatment plant in the city of Chillán $\left(36^{\circ} 36^{\prime} \mathrm{S} ; 72^{\circ} 07^{\prime}\right.$ W). This treatment plant has a biological treatment system with activated sludge and generates between 500 to $600 \mathrm{t}$ of fresh sludge each month. Sludge was pressed and taken to a drying field. Fresh sludge samples ( $80 \%$ humidity) were obtained at the pressing equipment discharge point and were immediately taken to the laboratory.

\section{Sample analysis}

The biological analyses of fresh sludge revealed low levels of fecal coliforms and Salmonella spp., which indicated that the sewage employed in this study classifies as acceptable material according to Chilean microbiological standards (BCN, 2009).

Before preparing the mixtures, soil and sewage were dried at room temperature and then sized sieved with a 2-mm screen. Subsequently, a representative sample was obtained from each one for chemical characterization (Table 1), which was performed with compound samples using the Sadzawka et al. (2006) soil methodology and methods recommended by Sadzawka et al. (2005) for

Table 1. Initial chemical characterization of Alfisol soil and sewage sludge.

\begin{tabular}{|c|c|c|}
\hline & Alfisol & $\begin{array}{c}\text { Sewage } \\
\text { sludge }\end{array}$ \\
\hline $\mathrm{pH}$ (water) 1:2.5 & 5.60 & 5.94 \\
\hline Organic matter, $\%$ & 2.53 & 41.95 \\
\hline $\mathrm{NO}_{3}-\mathrm{N}, \mathrm{mg} \mathrm{kg}^{-1}$ & 6.50 & 17.10 \\
\hline $\mathrm{NH}_{4}-\mathrm{N}, \mathrm{mg} \mathrm{kg}^{-1}$ & 3.30 & 424.00 \\
\hline Available $\mathrm{N}, \mathrm{mg} \mathrm{kg}^{-1}$ & 9.80 & 441.10 \\
\hline Olsen-P, mg kg-1 & 5.40 & 853.20 \\
\hline $\mathrm{K}, \mathrm{mg} \mathrm{kg}^{-1}$ & 129.80 & 5591.00 \\
\hline $\mathrm{Al}, \operatorname{cmol}(+) \mathrm{kg}^{-1}$ & 0.02 & 0.01 \\
\hline $\operatorname{ECEC}, \operatorname{cmol}(+) \mathrm{kg}^{-1}$ & 5.49 & 42.69 \\
\hline $\mathrm{S}, \mathrm{mg} \mathrm{kg}^{-1}$ & 1.70 & 24.60 \\
\hline $\mathrm{Fe}, \mathrm{mg} \mathrm{kg}^{-1}$ & 8.30 & 836.00 \\
\hline $\mathrm{Mn}, \mathrm{mg} \mathrm{kg}^{-1}$ & 7.60 & 204.00 \\
\hline $\mathrm{Zn}, \mathrm{mg} \mathrm{kg}^{-1}$ & 1.00 & 216.00 \\
\hline $\mathrm{Cu}, \mathrm{mg} \mathrm{kg}^{-1}$ & 2.00 & 4.80 \\
\hline $\mathrm{B}, \mathrm{mg} \mathrm{kg}^{-1}$ & 0.10 & 10.60 \\
\hline Total N, \% & 0.15 & 5.47 \\
\hline Ratio C/N & 9.30 & 4.50 \\
\hline
\end{tabular}

ECEC: effective cation exchange capacity. 
sewage sludge. The physical and chemical analyses were performed in the laboratories of the Department of Soil and Natural Resources, Faculty of Agronomy, Universidad de Concepción, Chillán Campus.

Analyses to determine the heavy metals present in the sludge (Table 2) were performed in the Environmental Chemical Laboratory of the Universidad de Concepción (accredited ISO 17025). Heavy metals can affect the soil's microbial biomass and enzymatic activities (Hernández et al., 1991) although the analyses indicated that these sludges complied with national and international standards.

Table 2. Heavy metal concentration (dry matter basis) present in sewage sludge.

\begin{tabular}{|c|c|c|}
\hline Metal & Sewage sludge & Limit $^{1}$ \\
\hline & mg & \\
\hline Arsenic (As) & 24.7 & 40 \\
\hline Cadmium (Cd) & $\mathrm{ND}$ & 40 \\
\hline Copper $(\mathrm{Cu})$ & 204.0 & 1200 \\
\hline Mercury (Hg) & 2.2 & 20 \\
\hline Nickel (Ni) & 9.5 & 420 \\
\hline Lead $(\mathrm{Pb})$ & 22.6 & 400 \\
\hline Selenium (Se) & 0.8 & 100 \\
\hline Zinc $(\mathrm{Zn})$ & 760.0 & 2800 \\
\hline
\end{tabular}

${ }^{1}$ Maximum metal concentration in sewage sludge applied to soil (BCN, 2009); ND: non-detectable.

\section{Establishment of assay and treatments}

This assay was carried out in pots inside a glass greenhouse of the Faculty of Agronomy of the Universidad de Concepción, Chillán. Each treatment was triplicated and performed on the basis of a different amendment $(15,30$, and $\left.60 \mathrm{t} \mathrm{ha}^{-1}\right)$ : LU15 = soil amended with $15 \mathrm{tha}^{-1}$ sludge; LU15-P = soil amended with $15 \mathrm{t} \mathrm{ha}^{-1}$ sludge + legume; LU30 $=$ soil amended with $30 \mathrm{t} \mathrm{ha}^{-1}$ sludge; LU30-P = soil amended with $30 \mathrm{t} \mathrm{ha}^{-1}$ sludge + legume; LU60 = soil amended with $60 \mathrm{t} \mathrm{ha}^{-1}$ sludge; LU60-P = soil amended with $60 \mathrm{t} \mathrm{ha}^{-1}$ sludge + legume. The controls were the following: $\mathrm{CS}=$ absolute control (non-amended soil, no crop); CS-P = non-amended soil, cropped.

To prepare the sludge-soil mixtures, $1 \mathrm{~kg}$ of soil plus the corresponding dose of sludge for each treatment was added to each pot. Then, the mixture was blended until homogenized and moistened with distilled water until field capacity was reached. Subsequently, each pot was covered with polyethylene bag and maintained for $1 \mathrm{mo}$. The assay began on 20 August 2009, and crop treatments were planted with yellow serradela (Ornithopus compressus L.) in the ratio of $1.5 \mathrm{~g}$ per pot with previously disinfected seeds $\left(\mathrm{HgCl}_{2}\right.$ for $\left.10 \mathrm{~min}\right)$. The test was maintained for 6 mo with soil moisture at 60 to $70 \%$ field capacity, and environmental temperature between 7 and $10^{\circ} \mathrm{C}$.

\section{Determination of microbial respiration}

The procedure is described by Celis et al. (2009) as: First, $25 \mathrm{~g}$ of wet sample per treatment (in triplicate) was placed in $1 \mathrm{~L}$ glass jars. Then, a test tube with $7.5 \mathrm{~mL}$ of $0.5 \mathrm{M} \mathrm{NaOH}$ and another with distilled water were prepared. The hermetically sealed jars were incubated at $22{ }^{\circ} \mathrm{C}$ for $60 \mathrm{~d}$. The amount of non-neutralized $\mathrm{NaOH}$ was measured at different times by titration with $0.1 \mathrm{M}$ $\mathrm{HCl}$ With the following procedure: $1 \mathrm{~mL}$ of $\mathrm{NaOH}$ was extracted, and $2 \mathrm{~mL}$ of $1 \mathrm{M} \mathrm{BaCl}_{2}$ were added. Then, drops of phenolphthalein were added as an acid-base indicator, and the non-neutralized $\mathrm{NaOH}$ was directly titrated with $0.1 \mathrm{M} \mathrm{HCl}$. The $\mathrm{CO}_{2}$ released from the incubated mixtures was calculated by Anderson's (1982) formula. Results were expressed as $\mu \mathrm{g} \mathrm{C}-\mathrm{CO}_{2} \mathrm{~g}^{-1}$ of soil on a dry weight basis (oven at $105{ }^{\circ} \mathrm{C}$ ). The determination of microbial respiration was performed in the Microbiology Laboratory of the Department of Soils of the Universidad de Concepción, Chillán.

\section{Enzymatic activities}

The procedure to determine $\beta$-glucosidase is described by Eivazi and Tabatabai (1988). First, $1 \mathrm{~g}$ of dry soil was mixed with $4 \mathrm{~mL}$ of a buffer solution MUB $\mathrm{pH} 6$ and $1 \mathrm{~mL}$ of $25 \mathrm{mM}$ p-nitrophenil- $\beta$-D-glucopiranoside (substrate); and the mixture was incubated in a water bath for $1 \mathrm{~h}$ at $37{ }^{\circ} \mathrm{C}$. Next, it was cooled; $1 \mathrm{~mL}$ of $0.5 \mathrm{M} \mathrm{CaCl}_{2}$ was added and then filtered in an extractive solution 0.1 M THAM-NaOH. The amount of p-nitrophenol (PNP) released was determined spectrophotometrically at 410 $\mathrm{nm}$. For each sample, the blank was a soil sample with added substrate after the incubation period, which refers to a nonspecific hydrolysis of p-nitrophenil phosphate. Enzyme $\beta$-glucosidase activity is expressed in $\mu$ moles PNP g ${ }^{-1} h^{-1}$.

The procedure to determine phosphatase acid is described by Tabatabai and Bremner (1969). First, $1 \mathrm{~g}$ of dry soil was mixed with $4 \mathrm{~mL}$ of buffer MUB pH 6.5 and $1 \mathrm{~mL} 0.05 \mathrm{M}$ p-nitrophenil phosphate. Then, samples were incubated in a water bath for $1 \mathrm{~h}$ at $37{ }^{\circ} \mathrm{C}$. Next, $1 \mathrm{~mL}$ of $0.5 \mathrm{M} \mathrm{CaCl}_{2}$ was added, shaken, and filtered (Whatman $\mathrm{N}^{\circ} 40$ ). The filtrate was received in $0.5 \mathrm{M}$ $\mathrm{NaOH}(4 \mathrm{~mL})$, homogenized, and centrifuged at $2800 \mathrm{rpm}$ for $5 \mathrm{~min}$. The amount of released PNP was determined spectrophotometrically at $400 \mathrm{~nm}$. Phosphatase acid enzyme activity is expressed as $\mu$ moles PNP g ${ }^{-1} \mathrm{~h}^{-1}$.

Urease was determined by the procedure described by Kandeler and Gerber (1988) and modified by Kandeler et al. (1999). First, $1 \mathrm{~g}$ of dry soil was mixed with $1 \mathrm{~mL}$ of $79.9 \mathrm{mM}$ urea as substrate. Then, it was shaken and 
incubated in a water bath for $2 \mathrm{~h}$ at $37^{\circ} \mathrm{C}$. Next, $13.5 \mathrm{~mL}$ of $1 \mathrm{M} \mathrm{KCl}$ was added, shaken for $30 \mathrm{~min}$, and then filtered. From the filtrate, $1 \mathrm{~mL}$ was extracted for replication, and $9 \mathrm{~mL}$ of distilled water was added to dilute the extract. To develop color, $5 \mathrm{~mL}$ of sodic salicilate dissolved in $\mathrm{NaOH}$ and $2 \mathrm{~mL}$ of a sodium dichloride-cyanide solution were combined and maintained at room temperature for $30 \mathrm{~min}$; absorbance was then measured on a spectrophotometer at $690 \mathrm{~nm}$. Each sample was compared with a blank prepared in the same way as the sample, except that distilled water was added rather than urea. Urease enzyme activity was expressed as $\mu$ moles $\mathrm{NH}_{4}^{+} \mathrm{g}^{-1} \mathrm{~h}^{-1}$.

The enzymatic determination (three replicates and two controls for each treatment) was performed in the Fungus Biotechnology Laboratory of the Science and Vegetal Technology Department of the Universidad de Concepción, Los Ángeles.

\section{Aboveground and root phytomass}

At the end of the assay, the amount of aboveground and root biomass was quantified in those treatments cropped with Ornithopus compressus L. Aboveground phytomass was evaluated by a circumscriptive cut to each pot with Teflon scissors at $1 \mathrm{~cm}$ of soil, including the entire aboveground biomass contained in the pot. To determine root biomass, roots were carefully separated from the soil cube contained in each pot, which had been previously air-dried. Subsequently, samples were placed in paper bags, separated, and labeled to determine their dry weight by gravimetry (forced ventilation oven at $70{ }^{\circ} \mathrm{C}$ for $72 \mathrm{~h}$ ).

\section{Statistical analysis}

The experimental design was a completely randomized design, and the values were arcsine-transformed before statistical analysis. All data were analyzed by factorial analysis of variance $(2 \times 4)$ by ANOVA with crop treatment, sewage sludge treatment, and their interaction as sources of variation. Statistical procedures were carried out with SAS version 8.1 for Windows (SAS Institute, Cary, North Carolina, USA). The statistical significance level was determined by Tukey $(\mathrm{p} \leq 0.05)$.

\section{RESULTS AND DISCUSSION}

The ANOVA result for respiration and enzymatic activities indicated significant interaction between legume and sludge dose.

In Table 3, an increase in microbial respiration is observed with increases in the amended doses of sewage, especially between the highest doses and the control ( $\mathrm{p} \leq$ 0.05 ). These results coincide with other studies (JezierskaTys and Frac, 2008; Celis et al., 2009), and are explained by the increased amount of OM and nutrients incorporated
Table 3. Effect of the interaction between legume (Ornithopus compressus L.) and sewage sludgeamended dose on microbial respiration at different incubation times.

\begin{tabular}{lcccc}
\hline & \multicolumn{4}{c}{ Incubation time (d) } \\
\cline { 2 - 5 } Treatments & $\mathbf{0}$ & $\mathbf{7 3}$ & $\mathbf{1 1 8}$ & $\mathbf{1 4 5}$ \\
\cline { 2 - 5 } & $289 \mathrm{e}$ & $209 \mathrm{~d}$ & $130 \mathrm{e}$ & $198 \mathrm{e}$ \\
CS & $727 \mathrm{~cd}$ & $635 \mathrm{c}$ & $480 \mathrm{c}$ & $450 \mathrm{~d}$ \\
LU15 & $850 \mathrm{c}$ & $831 \mathrm{~b}$ & $423 \mathrm{~cd}$ & $540 \mathrm{~cd}$ \\
LU30 & $1190 \mathrm{a}$ & $1050 \mathrm{a}$ & $725 \mathrm{~b}$ & $610 \mathrm{~cd}$ \\
LU60 & $325 \mathrm{e}$ & $310 \mathrm{~d}$ & $331 \mathrm{~d}$ & $630 \mathrm{c}$ \\
CS-P & $600 \mathrm{~d}$ & $750 \mathrm{bc}$ & $538 \mathrm{~cd}$ & $1086 \mathrm{~b}$ \\
LU15-P & $1015 \mathrm{~b}$ & $638 \mathrm{c}$ & $692 \mathrm{~b}$ & $1580 \mathrm{a}$ \\
LU30-P & $1280 \mathrm{a}$ & $1050 \mathrm{a}$ & $882 \mathrm{a}$ & $1490 \mathrm{a}$ \\
LU60-P & &
\end{tabular}

CS: soil without legume, not amended; LU15: amended soil with $15 \mathrm{t}^{-1}$ sewage sludge; LU30: soil amended with $30 \mathrm{t} \mathrm{ha}^{-1}$ sewage sludge; LU60: soil amended with $60 \mathrm{t} \mathrm{ha}^{-1}$ sewage sludge; CS-P: soil with legume, not amended; LU15-P: amended soil with $15 \mathrm{t} \mathrm{ha}^{-1}$ sewage sludge + legume; LU30-P: amended soil with $30 \mathrm{t} \mathrm{ha}^{-1}$ sewage sludge + legume; LU60-P: amended soil with $60 \mathrm{t} \mathrm{ha}^{-1}$ sewage sludge + legume.

Different letters in the same column indicate significant differences $(\mathrm{p} \leq 0.05)$.

into the soil, which is due to the larger quantity of amended residues stimulating microbial activity (Acosta-Martínez and Tabatabai, 2000; Fernández et al., 2007).

Moreover, there was a high $\mathrm{C}-\mathrm{CO}_{2}$ production in the first sampling followed by a progressive decrease with incubation time, except for the legume treatments in the last sampling (145 d) when microbial respiration increased. This increase is explained by the crop's greater biomass development in this stage, which became an additional source of $\mathrm{C}$ that increased soil microorganism respiration rate (Ros et al., 2003).

The initial increase in respiration can be attributed to the incorporation of easily biodegradable material, which stimulates the soil's natural microbial activity, as well as adding exogenous microorganisms to the sludge (GarcíaGil, 2000; Saviozzi et al., 2002). Results obtained also coincide with those reported by García et al. (1997) who observed that microbial respiration decreased over time because of the depletion of labile $\mathrm{C}$ and reached values similar to non-amended soil. In contrast, treatments with legumes showed an increase in microbial respiration over time. Plant cover is important due to nutrients and $\mathrm{C}$ added by root discharge and plant residues that favor the soil's microbial respiration and compensate the loss of $\mathrm{C}$ produced by high initial mineralization (Pascual et al., 1999; Tejada et al., 2006).

Table 4 shows aboveground and root biomass obtained at the end of the assay for treatments cropped 
Table 4. Aboveground and root biomass for treatments amended with sewage sludge and cropped with legume (Ornithopus compressus $\mathbf{L}$.) at the end of the assay.

\begin{tabular}{|c|c|c|}
\hline Treatments & $\begin{array}{l}\text { Aboveground } \\
\text { biomass }\end{array}$ & $\begin{array}{c}\text { Root } \\
\text { biomass }\end{array}$ \\
\hline & & . \\
\hline CS-P & $5.2 \mathrm{~b}$ & $4.3 b$ \\
\hline LU15-P & 7.8ab & $6.5 \mathrm{a}$ \\
\hline LU30-P & $8.8 \mathrm{a}$ & $7.6 \mathrm{a}$ \\
\hline LU60-P & $8.7 \mathrm{a}$ & $7.9 \mathrm{a}$ \\
\hline CV (\%) & 157 & 11.0 \\
\hline
\end{tabular}

CS-P: soil with legume, not amended; LU15-P: amended soil with $15 \mathrm{t} \mathrm{ha}^{-1}$ sewage sludge + legume; LU30-P: amended soil with $30 \mathrm{t} \mathrm{ha}^{-1}$ sewage sludge + legume; LU60-P: amended soil with $60 \mathrm{t} \mathrm{ha}^{-1}$ sewage sludge + legume; CV: coefficient of variation. Different letters in the same column indicate significant differences $(\mathrm{p} \leq 0.05)$.

with Ornithopus compressus L. All treatments amended with sewage significantly produced more phytomass ( $\mathrm{p}$ $\leq 0.05)$ than non-amended treatments (CS-P). Biomass tended to increase with higher amended doses, especially in the roots. Applying sewage stimulated $O$. compressus
L. growth in degraded Alfisol soil, and this agrees with results of other crops in different environments (Hernández et al., 1991; Marambio and Ortega, 2003).

Figure 1 shows phosphatase acid enzymatic activity. A significant increase of the enzyme can be observed in all treatments as sewage dose increases, except in the final stage of the assay ( $145 \mathrm{~d})$. However, this activity was higher for treatments with crops $(\mathrm{p} \leq 0.05)$ than treatments without crops, indicating the beneficial incorporation of $\mathrm{C}$ into the soil produced by the leguminous species (Ros et al., 2003). At the end of the assay, phosphatase acid activity was almost twice in the control and the 15 and 30 $\mathrm{t} \mathrm{ha}^{-1}$ doses. This coincided with greater crop development and demonstrated the beneficial contribution of the leguminous crop to the soil. However, enzymatic activity was not proportional to sewage dose with phosphatase acid decreasing significantly ( $\mathrm{p} \leq 0.05)$ at $60 \mathrm{t} \mathrm{ha}^{-1}$ sludge. This decrease could be due to an increase in available $\mathrm{P}$ with regard to other treatments since there would be an inverse relationship between available $\mathrm{P}$ levels and enzymatic activity (Moscatelli et al., 2005; Criquet et al., 2007).
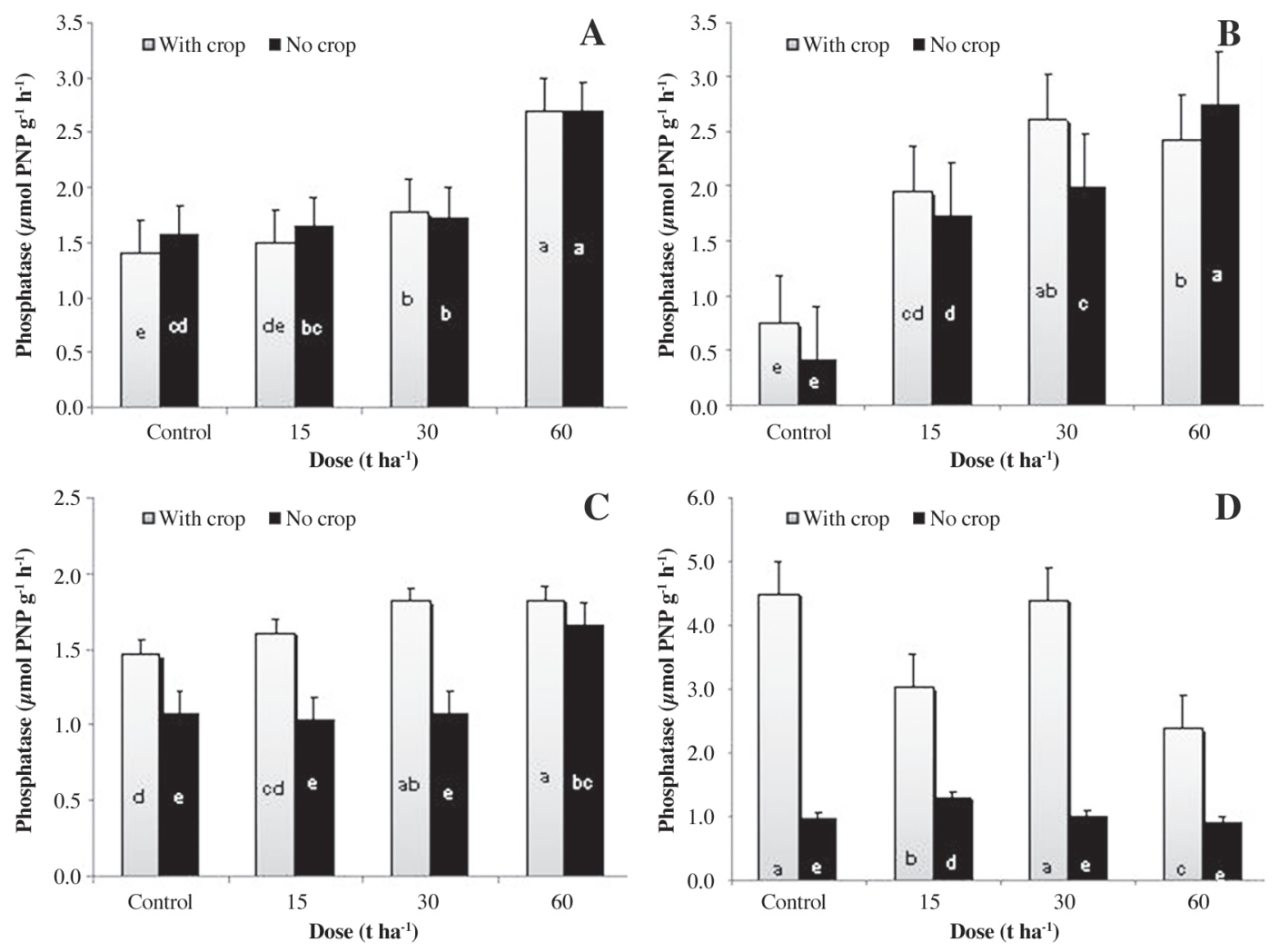

Different letters for same incubation time indicate significant differences $(\mathrm{p} \leq 0.05)$. PNP: $\mathrm{p}$-nitrophenol.

Figure 1. Interaction between legume (Ornithopus compressus $\mathrm{L}$.) and sewage sludge-amended dose for acid phosphatase during 0 (A), 73 (B), 118 (C), and $145 \mathrm{~d}$ (D) incubation. 
$\beta$-Glucosidase was higher in the treatments with leguminous crops (Figure 2), which could be due to a greater incorporation of $\mathrm{C}$ sources through organic and plant residues generated by the crops (Ros et al., 2003). The leguminous plants had a positive influence on this enzyme's activity; this agrees with García et al. (1997) and Bandick and Dick (1999) who measured high $\beta$-glucosidase activity in soil cropped with leguminous and cereal species. Pascual et al. (2007) reported that adding sewage sludge to soil significantly enhanced $\beta$-glucosidase activity, probably because sewage sludge has a high amount of utilizable substrates for microbial growth.

Greater urease activity is observed in the treatments amended with sludge and cropped with leguminous species (Figure 3). However, all treatments exhibited a significant increase in urease activity $(\mathrm{p} \leq 0.05)$ at 60 $\mathrm{t} \mathrm{ha}^{-1}$ sewage. Greater enzyme activity at the highest amendment dose could be due to the larger quantity of nitrogenated compounds provided by sewage sludge. This explanation coincides with Bonmati et al. (1985) who associate higher urease levels with large amounts of $\mathrm{N}$ contained in organic residue that stimulates this enzyme's activity.
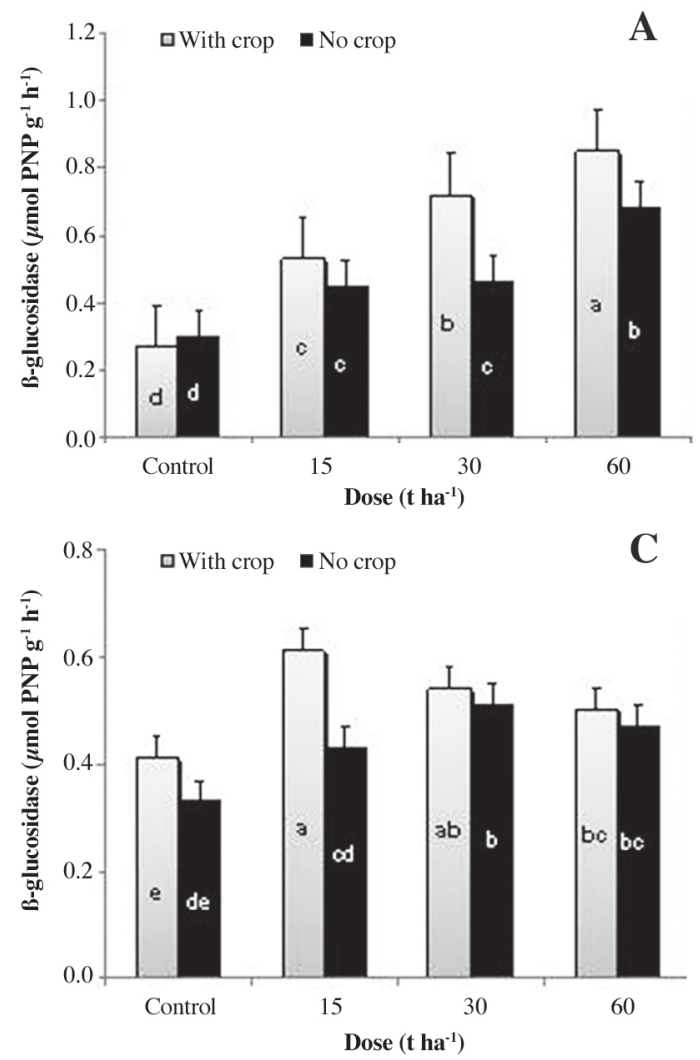

Results indicate a direct relationship between soil microbial and enzymatic activity as previously reported by Tabatabai (1994). In general, enzymatic activity in the initial states of the assay agrees with Kizilkaya and Bayrakli (2005) who indicate that this is due to the presence of easily decomposing substrates provided by sewage. Furthermore, activity over time in treatments without crops coincides with Madejón et al. (2001) who associate the progressive decrease of enzymatic activity with the lack of plants. Speir et al. (1980) established that enzymatic activity decreases rapidly in fallow soils while maintained in soils with crops because of enzymes released by plant roots and soil microorganisms. Indeed, only the presence of plant residues favors enzymatic activity by increasing OM content in Alfisol soils in southern Chile (Alvear et al., 2006). Furthermore, Tang and Yu's (1999) data indicate that the leguminous rhizosphere helps enzymatic activity, and suggest the possibility that this crop has unique, inherent characteristics that stimulate this activity (Bandick and Dick, 1999). It seems important to favor plant cover establishment not only to physically protect the soil surface but also improve its biological quality.
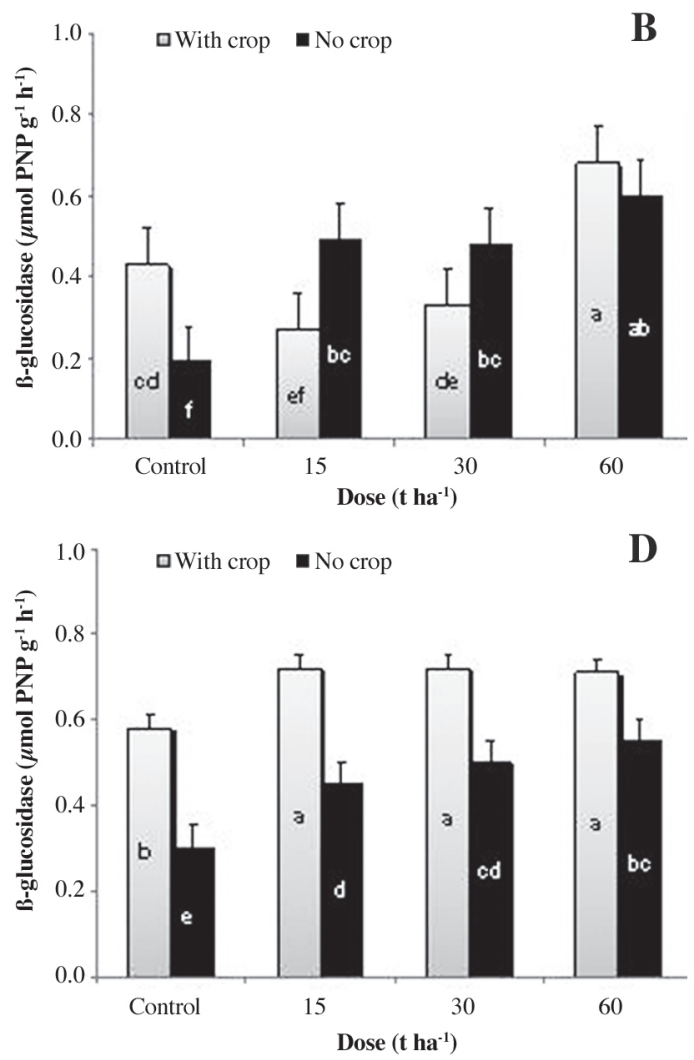

Different letters for same incubation time indicate significant differences ( $\mathrm{p} \leq 0.05)$. PNP: $\mathrm{p}$-nitrophenol.

Figure 2. Interaction between legume (Ornithopus compressus $\mathrm{L}_{\text {.) }}$ and sewage sludge-amended dose for $\beta$-glucosidase during 0 (A), 73 (B), 118 (C), and $145 \mathrm{~d}(\mathrm{D})$ incubation. 

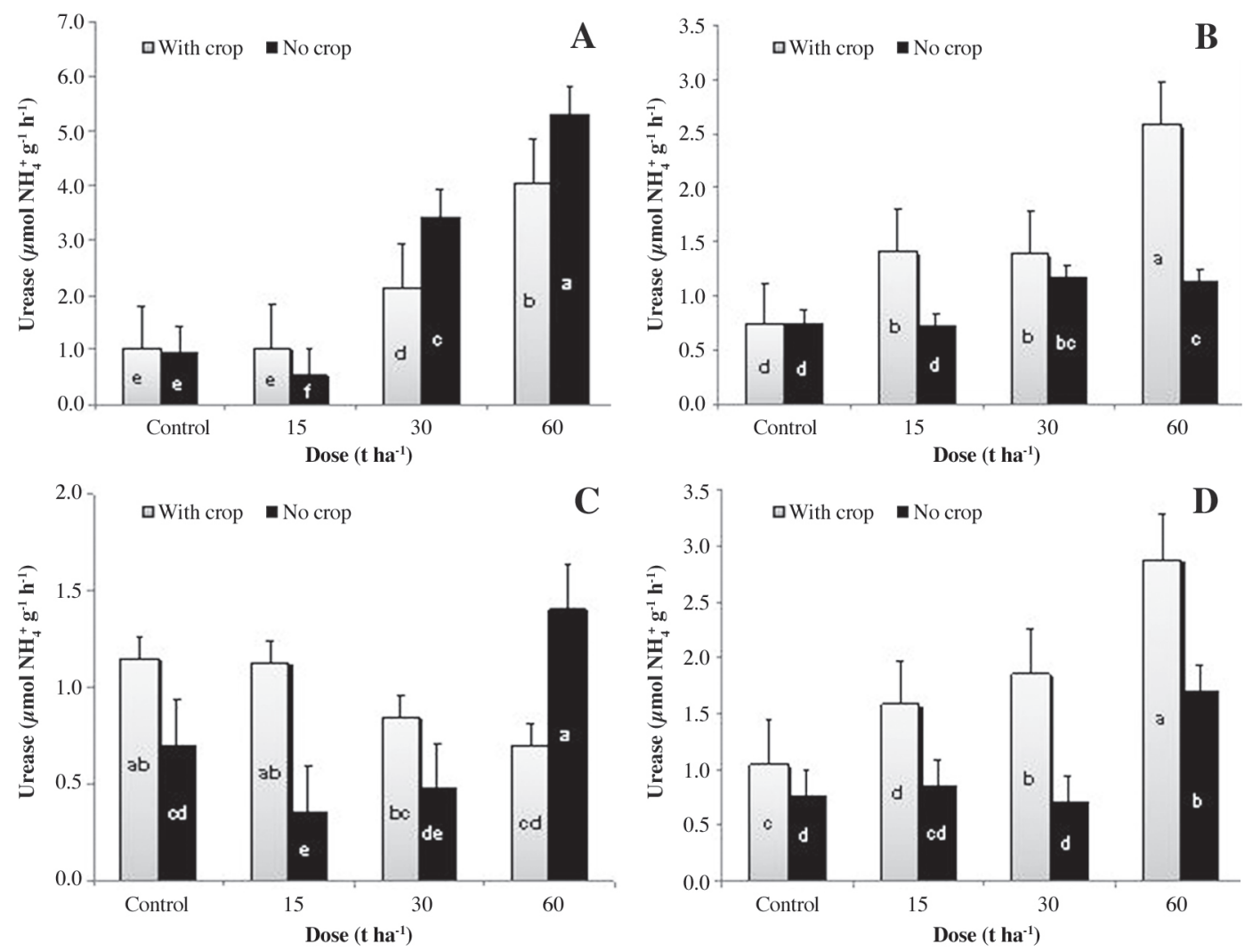

Different letters for same incubation time indicate significant differences $(\mathrm{p} \leq 0.05)$.

Figure 3. Interaction between legume (Ornithopus compressus $\mathrm{L}_{\text {.) }}$ and sewage sludge-amended dose for urease during 0 (A), 73 (B), 118 (C), and $145 \mathrm{~d}$ (D) incubation.

\section{CONCLUSIONS}

Different sewage amendments affected the biological activity of the degraded Alfisol. An increase in microbial respiration and enzymatic activity was directly related to sewage dose, and its effect is more significant when soil amendment is combined with the establishment of the leguminous crop, Ornithopus compressus L. The greatest increase of $\mathrm{CO}_{2}$-C, phosphatase acid, $\beta$-glucosidase, and urease activity coincided with greater crop aboveground and root development. The positive effect of sewage amendment, combined with the contribution of $O$. compressus $\mathrm{L}$. on the biological properties studied, could stop the high degree of degradation exhibited by the dryland Alfisol soils. These preliminary results indicate that it is possible to recover a lot of eroded soils that have lost their productive capacity and could also provide a disposal solution for sewage plant residues. Long-term in situ research integrating edaphic, agronomic, and environmental aspects is required to ensure adequate natural resource protection.

\section{ACKNOWLEDGEMENTS}

This study was financed by project $\mathrm{N}^{\circ}$ 208.153.0181.0 of the Dirección de Investigación, Universidad de Concepción.

\section{RESUMEN}

Actividad biológica en un Alfisol degradado enmendado con lodos urbanos y cultivado con serradela amarilla (Ornithopus compressus L.). El impacto de los lodos urbanos sobre las propiedades biológicas en suelos Alfisoles del secano interior de la Cordillera de la Costa de Chile ha sido poco estudiado. El objetivo de este estudio fue evaluar el efecto de la aplicación de lodo urbano sobre las propiedades biológicas de un suelo Alfisol degradado de la Región del Bío Bío, Chile, cultivado con serradela amarilla (Ornithopus compressus L.). Se adicionó lodo al suelo a razón de 15, 30 y $60 \mathrm{t} \mathrm{ha}^{-1}$, a partir de lo cual se definieron 
los siguientes tratamientos: L15-P $=15 \mathrm{t} \mathrm{ha}^{-1}$ lodo $+O$. compressus; $\mathrm{L} 30-\mathrm{P}=30 \mathrm{t} \mathrm{ha}^{-1}$ lodo + O. compressus; $\mathrm{L} 60-\mathrm{P}$ $=60 \mathrm{tha}^{-1}$ lodo $+O$. compressus $; \mathrm{L} 15=15 \mathrm{tha}^{-1}$ lodo $; \mathrm{L} 30=$ 30 t ha $^{-1}$ lodo; $\mathrm{L} 60=60 \mathrm{t} \mathrm{ha}^{-1}$ lodo; $\mathrm{CP}=$ suelo sin enmendar, con cultivo; $\mathrm{C}=$ suelo sin enmendar, sin cultivo. Se evaluó la actividad de los microorganismos del suelo a través de pruebas de respirometría, se determinó la actividad de las enzimas hidrolíticas representativas de los ciclos del C, N y P en el suelo, y se evaluó el desarrollo de la fitomasa del cultivo. Se encontró un aumento $(\mathrm{p} \leq 0,05)$ del $\mathrm{C}-\mathrm{CO}_{2}$ respirado por los microorganismos del suelo en proporción directa con las dosis de lodo. Del mismo modo, hubo una mayor actividad de las enzimas $\beta$-glucosidasa, ureasa y fosfatasa ácida a 60 t ha ${ }^{-1}$ de lodo. Sin perjuicio de lo anterior, tanto la actividad respiratoria como la actividad enzimática fueron superiores ( $p$ $\leq 0,05$ ) en los tratamientos con suelo enmendado con lodo y cultivado con $O$. compressus. Esta mayor actividad fue más notoria cuando la leguminosa alcanzó el mayor desarrollo de su fitomasa, destacándose el efecto estimulante de las raíces en la actividad biológica del suelo.

Palabras clave: respiración, actividad enzimática, biosólidos, suelos degradados, remediación.

\section{LITERATURE CITED}

Acosta-Martinez, V., and M.A. Tabatabai. 2000. Enzyme activities in a limed agricultural. Soil Biology and Fertility Soils 31:85-89.

Alvear, M., M. Pino, C. Castillo, C. Trasar-Cepeda, and F. Gil-Sotres. 2006. Efecto de la cero labranza sobre algunas actividades biológicas en un Alfisol del sur de Chile. Revista de la Ciencia del Suelo y Nutrición Vegetal 6:38-53.

Anderson, J.P. 1982. Soil respiration. p. 831-871. In Page, A.L., et al. (eds.) Methods of soil analysis. Chemical and Microbiological Properties. American Society of Agronomy, Madison, Wisconsin, USA.

Arriagada, C., P. Pacheco, G. Pereira, A. Machuca, M. Alvear, and J. Ocampo. 2009. Effect of arbuscular mycorrhizal fungal inoculation on Eucalyptus globulus seedlings and some soil enzyme activities under application of sewage sludge amendment. Revista de la Ciencia del Suelo y Nutrición Vegetal 9:89-101.

Bandick, A.K., and R.P. Dick. 1999. Field management effects on soil enzyme activities. Soil Biology and Biochemistry 31:1471-1479.

BCN. 2009. Reglamento para el manejo de lodos generados en plantas de tratamiento de aguas servidas. Biblioteca del Congreso Nacional, Santiago, Chile. Available at http://www.chileresiduos.cl/chileresiduos/userfiles/ file/DTO-4_28-OCT-2009.pdf (Accessed November 2010).
Bonmati, M., J. Pujola, F. Sana, M. Soliva, M. Felipo, B. Garau, et al. 1985. Chemical properties populations of nitrite oxidizers, urease and phosphatase activities in sewage sludge-amended soil. Plant and Soil 84:79-91.

Bronick, C.J., and R. Lal. 2005. Soil structure and management: A review. Geoderma 124:3-22.

Celis, J., M. Sandoval, and R. Barra. 2008. Salmon wastes and sewage sludge as organic fertilizer for plant response on two Chilean degraded soils under greenhouse conditions. Chilean Journal of Agricultural Research 68:274-283.

Celis, J., M. Sandoval, y M. Briones. 2007. Bioensayos de fitotoxicidad de residuos orgánicos en lechuga y ballica anual realizados en un suelo Alfisol degradado. Revista de la Ciencia del Suelo y Nutrición Vegetal 7:51-56.

Celis, J., M. Sandoval, y E. Zagal. 2009. Actividad respiratoria de microorganismos en un suelo patagónico enmendado con lodos salmonícolas. Archivos de Medicina Veterinaria 41:275-279.

Crecchio, C., A. Gelsomino, R. Ambrosoli, J. Minati, and P. Ruggiero. 2004. Functional and molecular responses of soil microbial communities under differing soil management practices. Soil Biology and Biochemistry 36:1873-1883.

Criquet, S., A. Braud, and S. Nèble. 2007. Short-term effects of sewage sludge application on phosphatase activities and available $\mathrm{P}$ fractions in Mediterranean soils. Soil Biology and Biochemistry 39:921-929.

Darwish, O.H., N. Persaud, and D.C. Martens. 1995. Effect of long-term application of animal manure on physical properties of three soils. Plant and Soil 176:289-295.

Eivazi, F., and M. Tabatabai. 1988. Glucosidases and galactosidases in soils. Soil Biology and Biochemistry 20:601-606.

Fernández, J.M., C. Plaza, D. Hernández, and A. Polo. 2007. Carbon mineralization in an arid soil amended with thermally-dried and composted sewage sludges. Geoderma 137:310-317.

García, C., T. Hernández, and A. Roldan. 1997. Changes in microbial activity after abandonment of cultivation in a semiarid Mediterranean environment. Journal of Environmental Quality 26:285-291.

García-Gil, J.C. 2000. Long-term effects of municipal solid waste compost application on soil enzyme activities and microbial biomass. Soil Biology and Biochemistry 32:1907-1913.

Hernández, T., J.L. Moreno, and F. Costa. 1991. Influence of sewage sludge application on crop yields and heavy metal availability. Soil Science and Plant Nutrition 37:201-210. 
Jezierska-Tys, S., and M. Frac. 2008. Microbiological indices of soil quality fertilized with dairy sewage sludge. International Agrophysics 22:215-219.

Joergensen, R., and C. Emmerling. 2006. Methods for evaluating human impact on soil microorganisms based on their activity, biomass, and diversity in agricultural soils. Journal of Plant Nutrition and Soil Science 169:295-309.

Kandeler, E., and H. Gerber. 1988. Short-term assay of soil urease activity using colorimetric determination of ammonium. Biology and Fertility of Soils 6:68-72.

Kandeler, E., M. Stemmer, and E.M. Klimanek. 1999. Response of soil microbial biomass, urease and xylanase within particle size fractions to long-term soil management. Soil Biology and Biochemistry 31:261-273.

Kizilkaya, R., and B. Bayrakli. 2005. Effects of N-enriched sewage sludge on soil enzyme activities. Applied Soil Ecology 30:192-202.

Madejón, E., P. Burgos, R. López, and F. Cabrera. 2001. Soil enzymatic response to addition of heavy metals with organic residues. Biology and Fertility of Soils 34:144-150.

Marambio, C., y R. Ortega. 2003. Uso potencial de lodos derivados del tratamiento de aguas servidas en la producción de cultivos en Chile. Revista Agronomía y Forestal UC 20:20-23.

Moscatelli, M.C., A. Lagomarsino, P. De Angelis, and S. Grego. 2005. Seasonality of soil biological properties in a poplar plantation growing under elevated atmospheric $\mathrm{CO}_{2}$. Applied Soil Ecology 30:162-173.

Ovalle, C., S. Arredondo, y O. Romero. 2006. Serradela amarilla (Ornithopus compressus) y serradela rosada (O. sativus): Dos nuevas especies de leguminosas forrajeras anuales para la zona mediterránea de Chile. Agricultura Técnica 66:196-209.

Ovalle, C., A. Del Pozo, J. Avendaño, y F. Fernández. 2005. Adaptación, crecimiento y producción de nuevas leguminosas forrajeras anuales en la zona mediterránea de Chile. Agricultura Técnica 65:265277.

Pascual, I., C. Antolin, C. García, A. Polo, and M. SánchezDíaz. 2007. Effect of water deficit on microbial characteristics in soil amended with sewage sludge or inorganic fertilizer under laboratory conditions. Bioresource Technology 98:29-37.

Pascual, J.A., C. García, and T. Hernández. 1999. Lasting microbiological and biochemical effects of the addition of municipal solid waste to an arid soil. Biology and Fertility of Soils 30:1-6.
Richardson, A. 2001. Prospects for using soil microorganisms to improve the acquisition of phosphorus by plants. Australian Journal of Plant Physiology 28:897-907.

Ros, M., M. Hernández, and C. García. 2003. Soil microbial activity after restoration of a semiarid soil by organic amendments. Soil Biology and Biochemistry 35:463-469.

Ros, M., J.A. Pascual, C. García, M.T. Hernández, and H. Insam. 2006. Hydrolases activities, microbial biomass and bacterial community in a soil after long-term amendment with different compost. Soil Biology and Biochemistry 38:3443-3452.

Sadzawka, R., M. Carrasco, R. Grez, y M. Mora. 2005. Métodos de análisis de compost. Serie Actas INIA N 30. Instituto de Investigaciones Agropecuarias INIA, Santiago, Chile.

Sadzawka, R., M. Carrasco, R. Grez, M. Mora, H. Flores, y A. Neaman. 2006. Métodos de análisis recomendados para los suelos de Chile. Revisión 2006. Serie Actas INIA $N^{\circ}$ 34. Instituto de Investigaciones Agropecuarias INIA, Santiago, Chile.

Saviozzi, A., P. Bufalino, R. Levi-Minzi, and R. Riffaldi. 2002. Biochemical activities in a degraded soil restored by two amendments: a laboratory study. Biology and Fertility of Soils 35:96-101.

Speir, T.W., R. Lee, E.A. Pansier, and A. Cairns. 1980. A comparison of sulphatase, urease and protease activities in planted and in fallow soils. Soil Biology and Biochemistry 12:281-291.

Tabatabai, M.A. 1994. Soil enzymes. p. 775-833. In R.W. Weaver et al. (eds.) Methods of soil analysis. Microbiological and Biochemical Properties. Soil Science Society of America, Madison, Wisconsin, USA.

Tabatabai, M.A., and J.M. Bremner. 1969. Use of p-nitrophenyl phosphate for assay of soil phosphatase activity. Soil Biology and Biochemistry 1:301-307.

Tang, C., and Q. Yu. 1999. Impact of chemical composition of legume residues and initial soil $\mathrm{pH}$ on $\mathrm{pH}$ change of a soil after residue incorporation. Plant and Soil 215:29-38.

Tejada, M., M.T. Hernández, and C. García. 2006. Application of two organic amendments on soil restoration: effects on the soil biological properties. Journal of Environmental Quality 35:1010-1017.

Waldrop, M.P., J.G. McColl, and R.F. Powers. 2003. Effects of forest postharvest management practices on enzyme activities in decomposing litter. Soil Science of America Journal 67:1250-1256. 